\title{
The Shadow of the Pithead: Understanding Social and Political Attitudes in Former Coal Mining Communities in the UK
}

\author{
Maria Abreu ${ }^{1}$ and Calvin Jones ${ }^{2}$
}

\begin{abstract}
The economic plight and consequent social and political attitudes of 'left behind' communities have become subjects of intense focus across a world impacted by inequality, social unrest, and political populism. We examine whether particular forms of long-term economic decline affect how residents in different places view the world; here in former coalmining communities of the UK which remain economically peripheral, and are home to community narratives that emphasise the shared economic, political and cultural heritages that are often fundamental those places' very existence. We use data from the UK Household Longitudinal Study to contrast political views and social attitudes in communities that were, in 1981, economically dependent on coal mining, with other communities that are similarly economically peripheral in contexts and challenges, but without a shared history of economic decline. We find that residents of former coalmining communities are highly politically disengaged, with low levels of trust and political efficacy, and low involvement in the political process. Moreover, our analysis shows an increase in political engagement over the Brexit campaign period, which directly addressed some of the grievances felt by these communities. We conclude that community narratives of economic peripherality are strongly inter-linked with trust in government and political engagement.
\end{abstract}

Keywords: peripherality, industrial decline, left-behind places, political efficacy, coal-mining.

\footnotetext{
${ }^{1}$ Corresponding author. Department of Land Economy, University of Cambridge, 19 Silver Street, Cambridge CB3 9EP, United Kingdom. E-mail: ma405@cam.ac.uk.

2 Cardiff Business School, Cardiff University, United Kingdom. E-mail: jonesc24@cardiff.ac.uk.
} 


\section{Introduction}

As it turns out, the world is far from flat. The pronouncements and predictions of the 1990s and early $21^{\text {st }}$ century that posited the end of history and emphasised the digitally-enabled birth of the weightless world have been gainsaid by a decade that has responded to the end of the Great Moderation and consequent economic pain by doubling down on the importance of place and identities, and the widening differences between them (Coyle 1999; Friedman, 2006; Fukuyama, 2006; Sandbu, 2020). Whilst place is far from the only lens with which to view the world, no major event of recent years, from the Great Recession through Brexit, COVID and Black Lives Matter, can be fully understood without considering where and how the people affected live - and with whom. Here, then we have the narrative of 'Left Behind Places', and the debate on how residence in economically peripheral places affects behaviours and attitudes, quite separately to an individual's level of economic success or engagement (Rodríguez-Pose, 2018; Abreu and Oner, 2020; Boswell et al., 2020). Across a number of (largely Western) countries, places can be identified at various scales where local economic conditions are strongly correlated with political discontent, which manifests in votes for challenger 'anti-establishment' or 'populist' parties, as well as general disenchantment with the political process (Stoker, 2006; Jennings et al., 2016; Hernandez, 2018). This narrative, however, is far from complete. There is an argument that some such behaviours are economically rational, or at least perceived rational; for example, in the case of Donald Trump's promise to bring manufacturing back to the USA. In other cases, such as deprived communities in receipt of substantial EU financial support voting for Brexit in the $\mathrm{UK}$, the rational economic case is more difficult to argue. This has led commentators to suggest that it is non-economic attitudes and conservative social mores that are driving voting behaviour (Norris and Inglehart, 2019). In both cases, there is little agreement on how such views emerge, and how they are affected by factors exogenous to local community, such as geographically targeted social media influencing 
(Cadwaller \& Graham-Harrison, 2018), or endogenous factors such as the wellbeing of friends and family, or the distinct social and economic characteristics of the community at hand.

In this paper we examine how far community identity and history can be identified as a differentiating factor in current residents' identity, social and cultural attitudes, and political preferences; and specifically, whether residence in a former coal mining community individual views and engagement in the political process. Former coal mining communities are located across much of Britain's geographical space (at scales ranging from 24,000 in North Wales to $1.25 \mathrm{~m}$ people in Yorkshire), but there is extensive evidence that such communities remain economically peripheral, in contrast to the sometimes impressive economic performance of neighbouring areas (Beatty et al., 2019). We suggest that theories and empirical findings that hint at the potential for economic peripherality (and the consequent attitudes and behaviours) to have important sociocultural impacts are under-researched, and require sophisticated framings to isolate the cultural from the purely economic determinants. We address this challenge by using a large-scale individual-level data set of UK residents and a non-parametric matching approach to estimate the contextual effect of living in areas with a shared history of long-term decline. Our results suggest that at least in coal mining towns, where industrial narratives endure and contribute strongly to shared cultural identities, this shared contextual effect is associated with higher levels of political disenchantment, regardless of personal circumstances.

The following section briefly recounts the debate on 'left behind places', then Section 3 explains why deprived former coal mining communities might comprise an interesting and distinct subset of such places. Section 4 presents our data and methodology, Section 5 outlines the results, and Section 6 discusses our findings in the context of academic and policy debates on marginalised communities and peripherality. Section 7 concludes and discusses implications for future research. 


\section{2 'Left Behind' Places}

We have, in the last 40 years, moved far from Galbraith's 'affluent' post-war economies, where income and work were sufficiently evenly distributed to protect social cohesion (Jones, 2015). The period since the 1980s has seen (generally) increasing levels of income and wealth inequality (Sandbu, 2020; Piketty 2020). These inequalities are related in complex ways to increased economic inequality between places, and to differences in the consequent levels of opportunity (Achten \& Lessmann, 2019; Costa et al., 2019). For example, in the UK, as in other countries, the economic performance of cities has a distinct regional flavour (Gardiner, 2020), and amongst regions, there is evident a strong peripherality-to-London effect that only Scotland avoids (Jones, 2015). Meanwhile, however, at lower spatial scales economic deprivation and consequent social ills are evident in a much more widespread fashion, be this in east London, or declining seaside resorts (Beatty et al., 2008; Carrascal-Incera et al., 2020; Boswell et al., 2020).

Increased spatial and individual inequality are related to changes in economic demand and employed technologies, which affect the relative productivity of, and demand for, unevenly distributed occupations, and the impact of globalisation in supply chains and consequent increases in trade and competition (Rodrik, 2018). The resulting concentration of economic mass, political power and (arguably) institutional competence in more successful places then constrains the spatial 'level playing field, making unevenness embedded and poverty 'sticky” (Myrdal, 1957; Jones, 2015; Ughetto et al., 2019; see McCann, 2016 for a comprehensive review of the UK case). The local plight of such places in driving individual 'discontent' with current socio-economic settlement has been increasingly recognised; for example Dijkstra et al. (2020) find it the dominant factor in driving anti-EU sentiment across the bloc. The picture is, however, far from straightforward. In the case of the 'Leave' vote in the 2016 Brexit referendum, Jump \& Michell (2020) find a positive association with local deprivation, but only if individual characteristics (such as education) are ignored. Beecham et al. (2020) argue that local socio-economic characteristics can explain some of 
the vote for Trump, but only outside the southern states. Meanwhile, places that appear socioeconomically similar do not necessarily behave in similarly populist/anti-establishment ways, even after allowing for demographic differences, as Nurse \& Sykes (2019) find for the Brexit vote on the Wirral and in Liverpool. In is difficult then to develop a straightforward explanation of how places shape individual 'discontent' and consequent behaviours.

We do know that individual characteristics, identity, and attitudes are vitally important in explaining recent bellwether events. For example, Barros \& Santos Silva (2019) argue that men suffering from labour market shocks during Brazil's economic crisis were drawn to Jair Bolsonaro's 2018 'masculine' defence of male economic status, whereas women rejected it in favour of 'pro-social' approaches; Renno (2018) further argues the Bolsonaro voter is more likely economically illiberal, and culturally and socially conservative. In the case of a vote for Trump 2016, racial attitudes and hard-line positions on the threat of immigration, rather than experience of its actual impacts, were important explanators (Reny et al., 2019; Whiteley et al. 2020). An especially interesting paper by Fabian et al. (2020) argues that notions of (community) identity are key to understanding the switch to Trump in the rust belt. Added to this already complex mix is the impact of deliberative action by (non-local) interest groups to motivate voting behaviours based on identity and worldview by emphasising points of anxiety via targeted social and other media (Del Vicario et al., 2017; Cadwalladr \& Graham-Harrison, 2018).

Fully understanding the disaffection that has had such an impact on global politics requires that we understand how individual attitudes and in-group identifications arise within economically peripheral places and how they interact with individual socio-economic characteristics and local socio-economic conditions. Further, unexplained differences in voting behaviour and attitude between outwardly similar people in largely similar places may be linked to levels of local relatedness, or community and social capital that are themselves an outcome of how and why communities were 'built', and which are sustained by community narratives that reference a 
happier industrial past - whether real or mythical. Such narratives can take enduring hold in communities that latterly feel ignored or 'othered' (McKenzie, 2017; Agnisola et al., 2019).

\section{Coal Mining and Community}

A strong narrative in popular culture suggests that there is something rather different and interesting about coalmining communities. Whilst one might struggle to remember in what sort of factory Terry and Bob of The Likely Lads worked ${ }^{3}$, the same is not true of the real and imagined characters of Pride or How Green was my Valley, where coal is key. The art-rock band Public Service Broadcasting memorialised the coal-mining industry in South Wales on Every V alley (before doing the same for another iconic industrial location on White Star Liner). In media descriptions, fable and reality largely overlap: the played-upon orientations of mining communities toward solidarity, leftist-politics, social justice, and resistance to an uncaring authority are revealed in the literature as much as they are reflected on film, song and print (Bell \& Braun, 2010; Sanz-Hernández, 2020). There is then a strong and coherent 'character' to such communities that is clear and narratable 4 Indeed, it does not need an academic treatise to realise that industrial heritage and memory shapes today's former coal mining communities more broadly, just a visit. The Durham Miners' Gala, still parading strong 25 years after the last pit closed, can be seen either as an exercise in stultifying nostalgia (Bloodworth, 2016) or an expression of communal identity for villages and county (Tomaney, 2020), but in either case it clearly means something.

Even if we accept that a common industrial history influences individual attitudes, identity and behaviour, this does of course not mean we know how. A communitarian ethos does not necessarily map well onto current political choices. More broadly, a keen sense of history may imbue members

\footnotetext{
${ }^{3}$ Ellison's Electrical.

4 Paul Robeson discovered his political voice after a chance meeting with Rhondda coal miners in 1929: After hearing their singing in a London street, he immediately joined their protest march and began a lifelong association with the Valleys that is fondly remembered today. https://www.theguardian.com/books/2017/jul/02/how-paul-robesonfound-political-voice-in-welsh-valleys.
} 
of coal mining communities with characteristics that are more right-leaning, and ally them in at least some regards with the populist right, and certainly with anti-establishment or 'metropolitan elite' narratives. For example, debates around climate change and renewable energy raise memories of past decline, and worry about the future (Olson-Hazboun, 2018; Mayer, 2019); gender identities may preclude (male) involvement in progressive activism (Bell \& Braun, 2010; Bell \& York, 2010); and 'resistant aspiration' may make young people reject an education system they see as preparing them to participate in an economy that has treated their families and communities badly (Bright, 2011).

To summarise, whilst the building blocks of a coal mining community ethos are easy to write down (solidarity; social justice; communitarianism; resistance), their implications for current attitudes and behaviours are uncertain. We can however expect, a priori, that if historically- and industrially rooted geographic relatedness is to have an impact on identity and action anywhere, it will be here, in these peripheral communities where belonging is so important ${ }^{5}$ (Emery, 2019). As a result, economic discontent arising from long-term economic decline might inform a collective disenchantment in a political system that has failed to address economic grievances, leading to low levels of trust and political disengagement (low political efficacy and low turnout), as well as increased support for challenger parties (in the form of a protest vote). We can therefore formulate the following two hypotheses:

Hypothesis 1: Peripheral communities with a history of economic decline have higher levels of community cohesion and belonging, relative to other comparable communities without a history of decline.

\footnotetext{
${ }^{5}$ Between 1999 and 2009 BBC Wales screened a soap opera set in the former coalfields called... Belonging.
} 
Hypothesis 2: Political discontent in peripheral communities with a history of economic decline manifests in lower levels of trust in the political system, lower levels of engagement, and greater support for challenger parties, relative to comparable communities without a history of decline.

\section{Data and Methodology}

Our aim is to analyse the effects of an economically salient past, followed by industrial decline, on current political engagement and social norms that shape voting behaviour. We focus on the UK's former coalmining communities as a case study in sudden industrial decline, which came about as the government closed down the publicly-owned mining industry in the mid-1980s. Since many former mining communities had been built specifically to house workers employed in the mines, and given the substantial shares of employment of the local population in the mines even in the early 1980s, the closure implied a very significant economic shock to these communities (Farrall, et al., 2020). While we are not able to identify a model that directly captures the impact of a coalmining heritage on political views and engagement (as there is no exogenous variation in economic decline, all similar areas having declined simultaneously), we use a matching approach to compare the social norms and voting behaviour of individuals in coal-mining areas, to very similar individuals in areas that are comparable in current economic terms, but lack the common experience and narrative of sudden industrial decline.

Our analysis uses individual-level data from the UK Longitudinal Household Survey (also known as "Understanding Society"), a nationally representative survey of just under 40,000 households. The fieldwork for each wave of the survey is carried out over a two-year period, so that there are overlaps between consecutive waves, i.e., Wave 1 was collected in 2009-2011, Wave 2 in 20102012, and so on. All household members aged 16 and over are included in the survey, and there is a separate shorter questionnaire for younger children. The data used in our analysis cover the period 2009-2019, collected in Waves 1-9 of the survey, with each household contacted once a 
year, at around the same date. Due to the complex sampling design of the survey, all our results are weighted using a combination of design and non-response weights.

In defining neighbourhoods, we use Lower Super Output Areas (LSOAs) as our spatial unit of analysis (and the equivalent Data Zones in Scotland), which are census areas with similar socioeconomic characteristics, made up of around 1,500 individuals. The LSOAs can in turn be mapped into larger administrative districts. Using LSOAs we are able to link the survey data to other administrative data sources, which include neighbourhood indices of material deprivation, indicators of rurality, and measures of state welfare spending. In addition, we use data by Beatty \& Fothergill (2013) on the extent of district-level cuts to state benefits, to capture the effect of the "austerity" programme that followed the 2011 general election. ${ }^{6}$

Our definition of coalmining communities is based on the share of employment in mining in the local area in 1981, before the economic reforms that led to the closure of the mines. We follow the approach of Beatty et al. (2019) in identifying areas with at least $10 \%$ of the adult male population employed in the "Energy and Water" sector in 1981, using 1981 Census data. Because this sector is very broad, and includes the emerging gas industry, as well as water treatment plans and other activities, we restrict the definition of coalmining communities to LSOAs falling within the relevant 1981 Census wards, but which are also located within 10 miles of geological bedrock coal deposits, defined using the Digital Geological Map Data of Great British 1: 625000 bedrock shapefile, provided by the British Geological Survey. ${ }^{7}$ Our definition includes all of the larger coalmining communities, although it excludes small coalmining areas that are geographically separate from the others, particularly the Kent coalfields. ${ }^{8}$

\footnotetext{
${ }^{6}$ See Appendix A for detailed descriptions of the variables included in the analysis, and Table B1 for descriptive statistics.

${ }^{7}$ We identified coal rock formations by searching for "coal" in the "RCS_X" field of the attribute table, which contains details of rock types in each formation. We then retained the formations identified as including coal and converted them into single polygons to create the geographically separate coalfield deposits.

${ }^{8}$ Figure $\mathrm{C} 1$ in Appendix C shows two maps that illustrate our method for defining coalfield communities.
} 
Our analysis consists of two parts. We first provide an overview of the main demographic and socio-economic differences between former coalmining communities and other areas. We then use a non-parametric matching method (Coarsened Exact Matching, or CEM) to match the individuals in our sample who live in former coalmining areas, to individuals with similar socioeconomic characteristics who live in areas that are similar in terms of deprivation, rurality, and in the same nation (England, Scotland, Wales), but which are not former coalmining areas. This allows us to balance the sample, and to identify differences in political views and behaviour of people living in communities that experienced rapid and sudden decline, versus those who are similarly poor, but who do not share the same history of community-wide decline. ${ }^{9}$

Our matching process produces a set of weights, which we use in conjunction with the design and non-response weights to create a balanced sample. We use this sample to analyse differences in social and cultural values, political efficacy, and voting norms, and in a further step, to observe the evolution of these values and norms over time, using weighted regressions (with the weights a combination of survey sampling and design weights, survey non-response weights, and our CEM weights). Our longitudinal results are based on a balanced panel of 14,380 individuals who responded to all nine waves of the survey, and for whom there are no missing values.

\section{Results}

Starting with demographic and socio-economic characteristics, shown in Table 1, we find that coalmining areas have a similar demographic profile to non-coalmining areas, with a similar age profile (coalmining areas are 0.8 years older, on average, but the difference is not statistically

\footnotetext{
${ }^{9}$ In practical terms, we coarsen continuous variables into categories, and reclassify categorical variables into broader categories. We then assign individuals to strata, so that within each strata all individuals have the same values for all of the coarsened matching variables. We use the strata to create weights to be used in further analysis. Individuals in strata without at least one treated and one control individual are assigned a zero weight and pruned from the data set in subsequent analysis (Iacus et al, 2008; Blackwell et al., 2009). Our matching variables are age, education, housing tenure, poor household (household below the national poverty line), Index of Multiple Deprivation (IMD) quintile for the LSOA, whether the LSOA is urban or rural, and nation (England, Scotland, Wales). Northern Ireland is excluded from the analysis as the data are not directly comparable to the other nations. Tables B2 and B3 in Appendix $\mathrm{B}$ provide details on the quality of the matching, and the resulting improvement in sample balance.
} 
significant), marital status, and number of children. Coalmining households tend to have slightly fewer household members ( 0.1 fewer members, a small difference that is nevertheless statistically significant), pointing to a larger number of individuals living alone or in smaller households, possibly as a result of greater housing availability. There are slightly fewer young people (aged 1824), and slightly more middle-aged people (aged 45-64), although the differences are small and only marginally statistically significant. Interestingly, the housing tenure profile is very similar, with no significant difference in the proportion of people living in owner-occupied and social housing in the two types of community.

The key differences lie in demographic diversity and education. Coalmining areas have a significantly higher proportion of white residents ( 7 percentage points higher), and a lower proportion of foreign-born residents (6 percentage points lower), indicating lower levels of immigration. The education profile is also very different to that of other areas, with fewer people in coalmining areas being educated to degree level (9 percentage points fewer), and coalmining areas having a lower-than-average school-leaving age (equivalent to leaving formal education 0.3 years earlier, on average).

Table 1. Demographic, economic, and local-area characteristics of coal-mining and other areas.

\begin{tabular}{lrrrc}
\hline Variable & Coalmining & Other areas & Difference & F (Wald test) \\
\hline Demographic variables & & & & \\
\hline Age (years) & 50.10 & 49.27 & 0.83 & 2.24 \\
Age 16-24 (\%) & 0.09 & 0.11 & -0.02 & $6.03^{* *}$ \\
Age 25-44 (\%) & 0.28 & 0.28 & 0.00 & 0.00 \\
Age 45-64 (\%) & 0.37 & 0.35 & 0.02 & $3.32^{*}$ \\
Age 65+ (\%) & 0.26 & 0.26 & 0.00 & 0.03 \\
White ethnicity (\%) & 0.98 & 0.91 & 0.07 & $238.92^{* * *}$ \\
Born in the UK (\%) & 0.97 & 0.90 & 0.06 & $118.00^{* * *}$ \\
Married or in civil partnership (\%) & 0.49 & 0.50 & -0.01 & 0.34 \\
Household size (number) & 2.66 & 2.80 & -0.14 & $8.72^{* * *}$ \\
Children (number) & 0.46 & 0.50 & -0.04 & 1.81 \\
Economic variables & & & & \\
\hline Owner-occupier (\%) & 0.69 & 0.68 & 0.01 & 0.36 \\
Social housing (\%) & 0.21 & 0.19 & 0.02 & 1.32 \\
Private tenant (\%) & 0.09 & 0.12 & -0.03 & $6.46^{* *}$ \\
School leaving age (years) & 16.07 & 16.39 & -0.31 & $89.16^{* * *}$ \\
Higher education qualification (\%) & 0.30 & 0.39 & -0.09 & $51.98^{* * *}$
\end{tabular}




\begin{tabular}{lrrrr} 
Working (if aged 18-65) (\%) & 0.51 & 0.53 & -0.02 & \multicolumn{1}{c}{2.02} \\
Receives any state benefits (\%) & 0.67 & 0.62 & 0.04 & $12.31^{* * *}$ \\
Number of benefits received & 1.72 & 1.53 & 0.19 & $13.25^{* * *}$ \\
Eq. monthly household income ( $($ ) & 1631.12 & 1876.22 & -245.09 & $52.11^{* * *}$ \\
Poor household (\%) & 0.19 & 0.14 & 0.05 & $16.91^{* * *}$ \\
Neighbourhood variables & & & & \\
\hline Index of Multiple Deprivation (IMD) & 24.09 & 20.51 & 3.57 & $34.06^{* * *}$ \\
Deprived area (\% of population) & 0.46 & 0.35 & 0.11 & $34.07^{* * *}$ \\
Urban area (\% of population) & 0.70 & 0.78 & -0.08 & $12.75^{* * *}$ \\
Annual austerity cuts per person $(£)$ & 527.64 & 458.74 & 68.90 & $194.53^{* * *}$ \\
\hline
\end{tabular}

Note: Column 5 shows the F-statistic for a difference-in-means Wald test across coalmining and other areas. The asterisks denote statistical significance of the F-statistic, where ${ }^{* * *}$ significant at $1 \%$ level, ${ }^{* *}$ significant at $5 \%$ level, * significant at $10 \%$ level. Higher values of the Index of Multiple Deprivation (IMD) indicate greater material deprivation in the neighbourhood. Austerity cuts per person refers to the average annual reductions in public spending resulting from the post-2011 austerity programme at the district level.

While employment rates are similar, coal-mining areas are significantly poorer, with lower average household incomes ( $£ 245$ or $\$ 320$ a week lower, after adjusting for household size), and a greater reliance on working-age state benefits (with residents being 4 percentage points more likely to receive state benefits, and receiving an average of 0.2 more types of state benefit), suggesting under-employment and low wages. Coalmining areas also have higher material deprivation scores, are more likely to fall into the $20 \%$ most deprived areas nationally (11 percentage points more likely). They were worse affected by the post-2011 public spending cuts, with the equivalent of a $£ 69$ or $\$ 90$ greater annual loss per person. Residents of coalmining areas are also less likely to live in urban neighbourhoods, relative to those in other areas (8 percentage points less likely).

Our next set of results, shown in Figure 1, are based on the matched sample, and therefore show a direct comparison between people living in coalmining areas, and similar people living in noncoalmining areas, where the latter areas are comparable to the former in terms of material deprivation and rurality. ${ }^{10}$

Using our matched sample, we find that self-reported levels of wellbeing (life-and job-satisfaction), are similar in both types of areas, as is self-reported physical health, but mental health is 10 The results shown in Figures 1 and 2 are based standardised variables, to allow for comparison. The graphs also
show 95\% confidence intervals, and a dashed line to indicate zero differences between coalmining and other areas. 
significantly lower in coalmining areas. Surprisingly, given the widespread belief that these coalmining towns are particularly close-knit and cohesive communities, we find that measures of community cohesion and neighbourhood belonging are not significantly different to those in other areas. In terms of social values, we find that residents of coalmining areas are slightly more socially progressive (as measured by agreement with the statement "family suffers if mother works"), but slightly more sceptical of the scientific consensus on climate change (as measured by agreement with "environmental crisis is exaggerated"). Residents of coalmining areas are also more risk averse (less "prepared to take risks"), and significantly more distrustful (less "prepared to trust strangers").

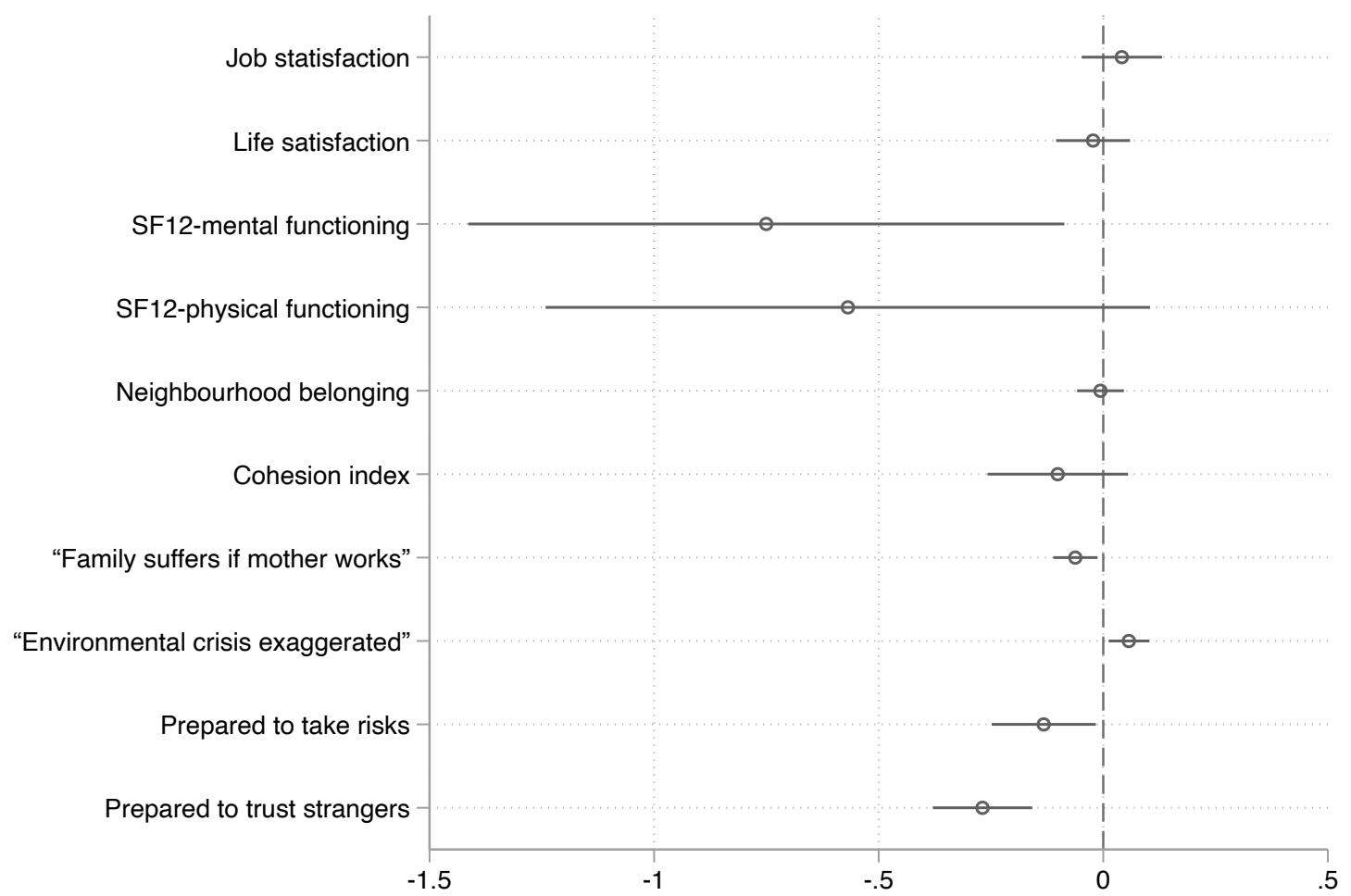

Figure 1. Effect of living in a coalmining area, relative to other areas, on wellbeing and social variables, for comparable individuals living in neighbourhoods with similar levels of deprivation and urban/rural profile. The figure shows sample average treatment effect (SATT) estimates and 95\% confidence intervals for standardised outcome variables. The SATT estimates are obtained using a weighted regression of the standardised outcome variable on a coalmining area dummy variable, with weights given by a combination of sampling and design weights, non-response rates, and Coarsened Exact Matching (CEM) weights.

Our next set of results, shown in Figure 2, refer to political engagement and voting behaviour. We find that coalmining areas have strikingly low levels of political efficacy across the board, including more negative views about the democratic process (low values of "democracy works well", "voting 
as a civic duty", and "personal benefits from voting"), and their ability to influence it (low values of "qualified to participate in politics", "well informed about politics", and high values of "public officials don't care", and "little say in what government does"). This also manifests as voter disengagement, with significantly lower interest in politics and lower voting intention. Interestingly, residents of coalmining areas are not dissimilar to those of comparably communities in levels of party-support or likelihood of voting for a nationalist party. Residents of coalmining areas were more likely to vote "leave" in the EU referendum, but the difference with other areas is small. Taken together, our results point towards communities that are distrustful of the government, feel they have little power to influence government decisions, and have low levels of political engagement.

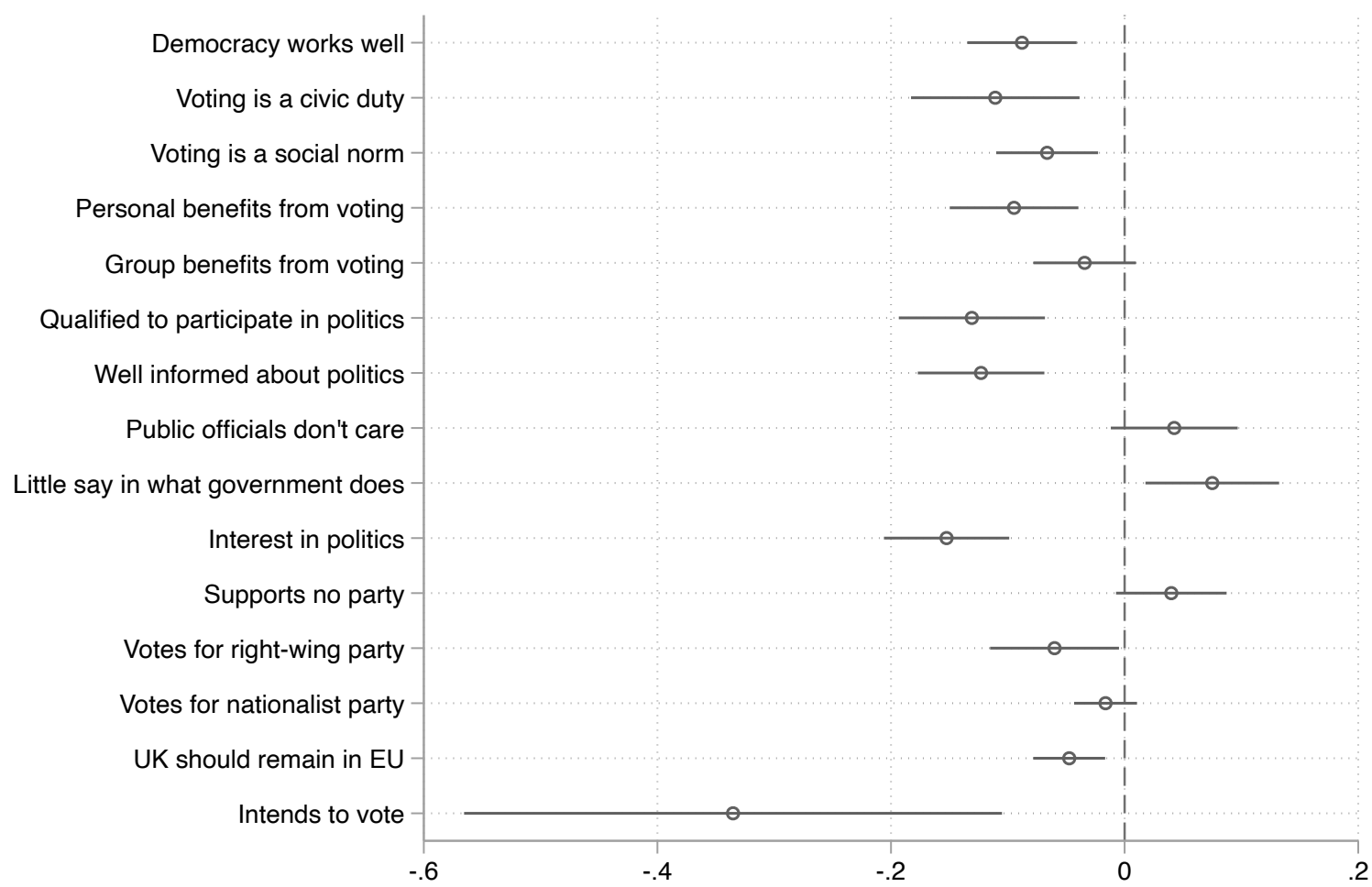

Figure 2. Effect of living in a coalmining area, relative to other areas, on political efficacy and engagement variables, for comparable individuals living in neighbourhood with similar levels of deprivation and urban/rural profile. The figure shows sample average treatment effect (SATT) estimates and 95\% confidence intervals for standardised outcome variables. The SATT estimates are obtained using a weighted regression of the standardised outcome variable on a coalmining area dummy variable, with weights given by a combination of sampling and design weights, nonresponse rates, and Coarsened Exact Matching (CEM) weights. 
Our final set of results looks at changes in political engagement and efficacy over time. These results are based on a balanced panel of individuals. ${ }^{11}$ Figure 3 shows that the level of interest in politics is consistently lower in coalmining areas than in comparable non-coalmining areas. However, there is an increase in interest in politics during the $2016 \mathrm{EU}$ referendum campaign, and in the period that follows. This suggests that the referendum campaign touched on themes that resonate strongly in former coalmining communities, and/or that the campaign targeted these areas in a way that traditional political campaigns do not normally do, although there is a more recent drop in political interest that suggests this effect may be wearing off. ${ }^{12}$

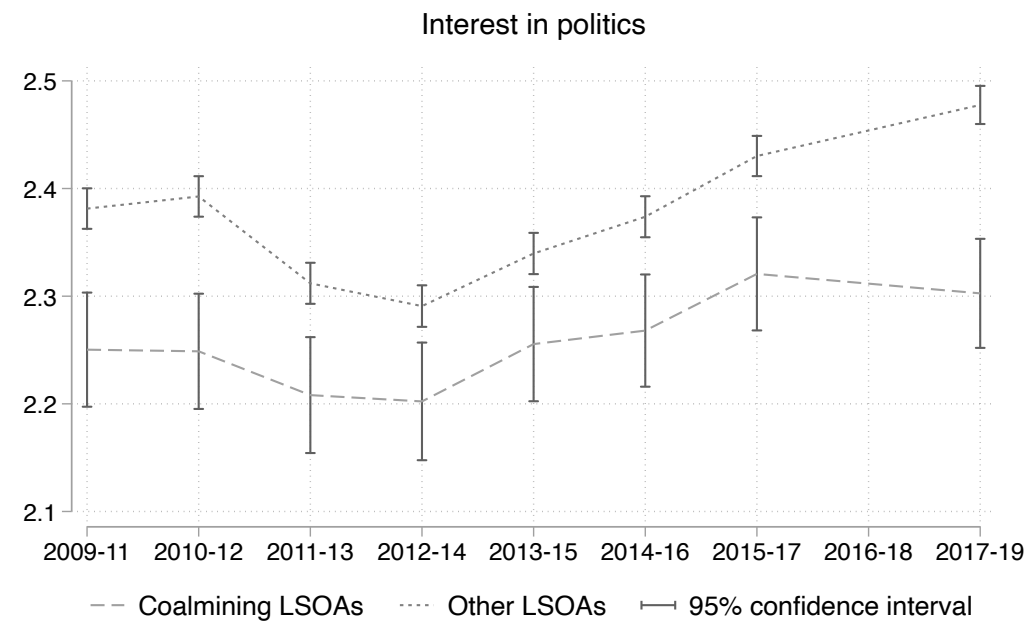

Figure 3. Interest in politics in coal-mining and other areas, over the period 2009-2019, showing average treatment effect (SATT) estimates and 95\% confidence intervals for individuals in the matched sample. The SATT estimates are obtained using a weighted regression of the standardised outcome variable on a coalmining area dummy variable, with weights given by a combination of sampling and design weights, non-response rates, and Coarsened Exact Matching (CEM) weights.

\footnotetext{
${ }^{11}$ Figure C2 in Appendix C shows the benefits of using our matching approach when considering change. In panel (a), we show equivalised monthly household income, deflated to adjust for inflation, for the full sample, while panel (b) shows the same graph, but based on our matched sample. In comparing the two panels we can see that the matching process initially results in parallel trends, with households in the two areas being similarly affected by the 2008-09 economic crisis and its aftermath. However, panel (b) shows that household incomes in coalmining areas recovered more slowly in the aftermath of the crisis, in part due to the austerity policies that followed in 2012. There were further hit by the economic slowdown that started in 2016.

12 Moreover, we see that the post-EU referendum period is associated with an increase in the number of people without a specific party allegiance, which is particularly striking in the former coalmining areas, that used to be Labour party strongholds (Figure C3).
} 
Figure 4 shows changes in political efficacy over time, using the matched sample. These figures are available for three waves of the survey only (Waves 3, 6, and 9). While people in coalmining areas consistently report lower levels of political efficacy, it is striking to see how it increases over the 2015-2016 EU referendum campaign period. All of the political efficacy measures shown, including personal benefits from voting, whether people feel qualified to participate in politics, and whether they feel well-informed about politics, increase over time, as do variables capturing political engagement as a social norm. Interestingly, we see a slight widening of the gap between coalmining areas and comparable non-coalmining areas in the final available period (2017-2019), suggesting that the increase in political engagement observed over the EU referendum period has started to tail off.
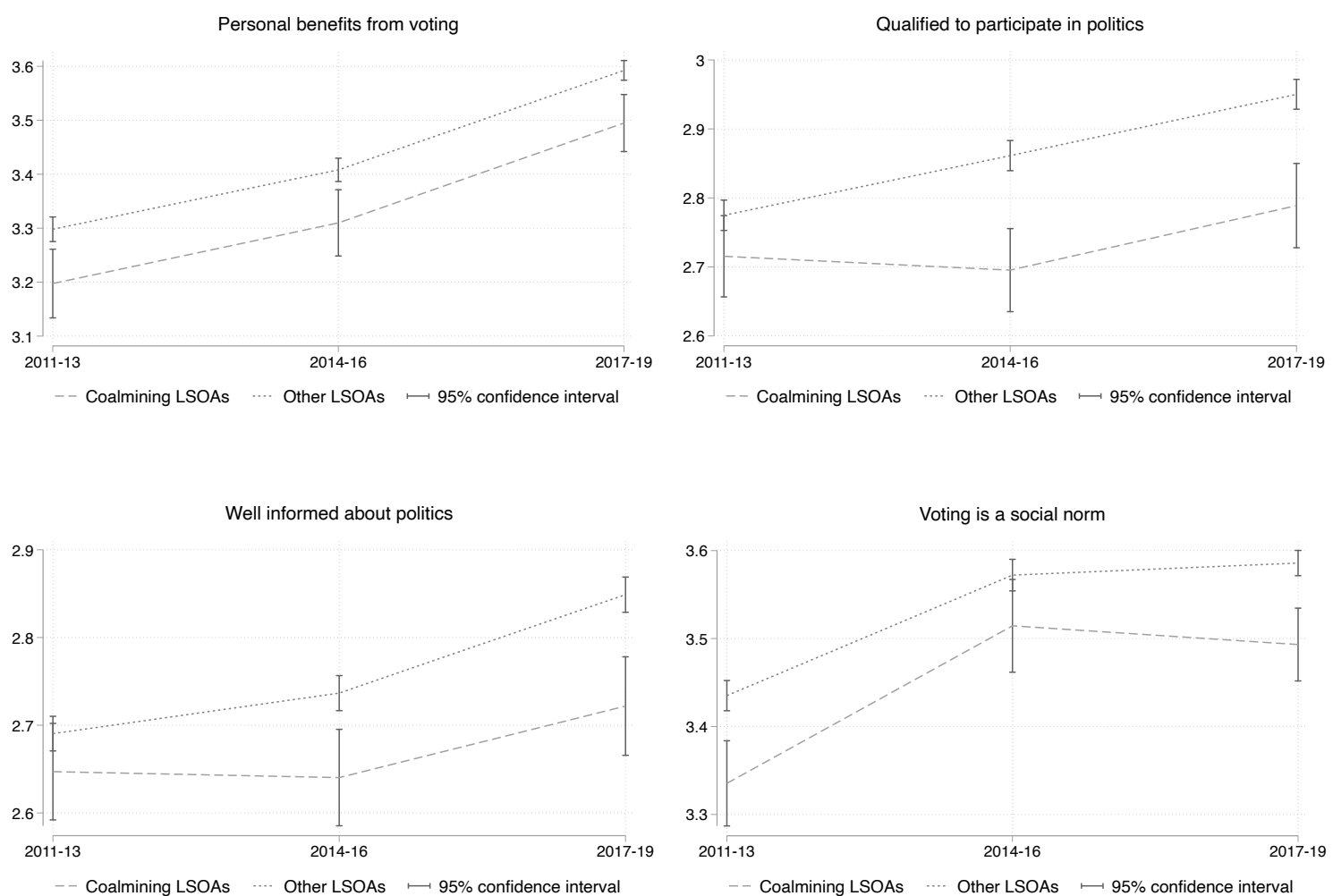

Figure 4. Political efficacy measures in coal-mining and other areas, over the period 2009-2019, showing average treatment effect (SATT) estimates and 95\% confidence intervals for individuals in the matched sample. The SATT estimates are obtained using a weighted regression of the standardised outcome variable on a coalmining area dummy variable, with weights given by a combination of sampling and design weights, non-response rates, and Coarsened Exact Matching (CEM) weights. 


\section{Discussion}

Our analysis of former coal mining communities reinforces some stereotypes, fails to support others, and nuances yet more. But in comparing attitudes in such places with those of largely alike people in largely alike communities in their home nations, we can certainly point to results that suggest that people in such places really do remain distinct.

Turning first, however, to points of no difference, we note that our results do not support the contention that coalfields retain higher levels of neighbourhood belonging and social cohesion than comparator areas, in contrast with the received wisdom, as postulated in our Hypothesis 1. There are a number of potential explanations here. With the deep coalmines almost universally closed by 1990 across the UK, it has been over thirty years since large numbers of people 'went on shift' underground ${ }^{13}$, and this is plenty of time for such relationships and networks to atrophy in the same way as many miners' halls, theatres and libraries fell into disrepair (Emery, 2020). A second alternative is that the levels of distinctive social cohesion and communitarian outlook simply never existed to the extent celebrated by media, politicians and residents themselves - or such characteristics had been in long term decline along with levels of employment in the pits themselves, since the great community project of the late $19^{\text {th }}$ and early $20^{\text {th }}$ centuries. Or thirdly, it may be that the even worse levels of deprivation and public sector austerity suffered by mining areas compared to other deprived places in their respective nations (see Table 1) have been sufficient to tear down distinctiveness in this regard. There is also a fourth, perhaps more hopeful interpretation. That the other deprived communities with whom we compare the coalfields - the peripheral social housing estates of Gorbals and Ely, the failing seaside towns of Margate and Rhyl, also have higher levels of social cohesion and community than their national average, but we just haven't noticed.

\footnotetext{
${ }^{13}$ Although mention must go of course to Tower Colliery in South Wales which soldiered on until 2008 after a worker buyout https://en.wikipedia.org/wiki/Tower Colliery.
} 
In other ways, people in coalmining areas do retain distinctive attitudes and characteristics, and these largely prior expectations and research (for example a lack of trust in messaging on environmental emergencies); and very specifically that around feelings of 'left-behindness' and othering leading to disenchantment and cynicism with politics and politicians, in support of our Hypothesis 2. Mining community residents are on almost all our measures (compared to matched individuals elsewhere) less interested in, and feel far less knowledgeable about, politics; they are less likely to have voted (and feel this is true of their neighbours), and far less likely to intend to vote at the next general election; and they (no doubt-relatedly) are more likely to think voting doesn't matter. It is difficult to say from where these attitudes stem, but the rhetoric of Margaret Thatcher and her government during the 1984-5 Miners' strike, with unionists portrayed as the UK's 'enemy within' with the USSR as the 'enemy without ${ }^{14}$, may cast a long shadow over a period and places for no new economic narrative or rationale has been found (Steber, 2018; Beatty et al., 2019).

Interestingly, however this level of disenchantment with politics has led to very nuanced outcomes. Those in mining communities are less likely to vote in elections or feel a strong affiliation with a political party, but this discontent also extends to newer populist parties, with those in mining communities less likely to vote for parties on the right (such as UKIP and The Brexit Party) compared to those in other deprived communities. At the same time, coalfields do not seem more likely to lean towards nationalist parties such as the SNP or Plaid Cymru - or indeed feel more 'Welsh' or 'Scottish' than their equally deprived counterparts elsewhere ${ }^{15}$.

We do however see engagement with, or at least some differences on, the EU question, with coalfield residents reporting a slightly higher Leave-orientation, after controlling for demographic and socio-economic characteristics. The framing of the EU Leave vote as a sui generis 'protest' from

\footnotetext{
${ }^{14}$ See https://the-enemy-within.org.uk/ for interviews, 30 years on, with those who were involved from the union side.

${ }^{15}$ Those in England's former mining communities do, however, feel more English.
} 
peripheral communities that felt ignored by mainstream politics, and excluded from economic opportunity, archetypically in the large coalfield of Leave-voting south Wales is supported by our results. Indeed, although causality is impossible to assign, the referendum looms large across the waves of our survey data more widely with post-2016 waves reporting higher levels of perceived political efficacy across all geographies, although with mining communities not showing the same growth in political interest and party support that we see elsewhere (Figure 4 and Figure C3).

It is important to note, at this point, that while our study provides support for the view that former coalmining communities are significantly politically disenchanted and disengaged, we are constrained in our analysis by the sparsity of spatially-representative data on the cultural norms and values of peripheral communities. A particularly interesting avenue for future research would be to analyse the role of demographic change (ageing and in- and out-migration), household composition, and slow-moving housing markets, in driving the observed patterns, using large-scale administrative data. Qualitative research on the values and aspirations of people living in peripheral communities, and how these intersect with local and national demographic trends, would also be particularly useful.

To summarise then, our approach of matching residents and deprived communities within the UK's nations reveals a number of differences between former coalfields and other places - and with these differences painting a coherent and intuitively attractive picture across a number of variables. We see a picture of people in mining communities who feel disenfranchised, ignored, and sceptical about political processes to a greater extent than elsewhere - and living in places where much vaunted communitarian ties are hard to evidence. We also see a picture, however of people who are less likely to be swayed by the promises of populist politicians and political parties. Here, the modern Left may not have lost the people to populism, the Nationalists or even the Conservatives, but to apathy and cynicism. 


\section{Conclusion}

Painting a picture of difference is one thing; explaining it is quite another. Here we can only say that personal attitudes, identity and perhaps even psychological character (Huggins \& Thompson, 2019) are affected by community character, and thus local economic and social history. In our coal mining case, generations of (largely) one-way migration have left these communities poorer, (on average) less educated, and overwhelmingly white; residents are risk averse, and (for better and worse) wary of outsiders, politicians, and the political process. They have significantly poorer levels of mental health. Yet residents also have, with the very arguable exception of the EU referendum, not appeared to respond to their condition with a lurch to the populist right, as have others in other places. Instead, the feeling from the data is of increased insularity, distrust and withdrawal from places and people 'outside'; almost an embrace of peripherality.

No doubt these attitudes are in part an outcome of multiple failed attempts to regenerate mining communities by 'outsiders', applying policies that are often not only adopted wholesale from other places and hence potentially ill-suited to mining communities, but which also lock in dependency and employ concepts and language (enterprise, entrepreneurship, property-led) that are essentially Thatcherite and hence almost guaranteed to engender scorn and failure (Diamond, 2004; Perchard, 2013; Pugh, 2014; Jones, 2015). So far, it appears that the devolution of UK political power, or more properly, some policymaking and policy administration, has done little to re-engage the coalfields, despite governments in Holyrood and Cardiff Bay (devolved Scottish and Welsh administrations, respectively) being at least notionally leftist and clearly concerned with the problem ${ }^{16}$. Holyrood and Cardiff Bay are still, after all, outside.

The question then turns to what can be done to 'save' these quirky, benighted, peripheral places? Past attempts, during happier economic times and supported in some cases by significant EU

16 See for example https://gov.wales/taskforce-valleys 
Cohesion Funds, have largely been failures. In a UK facing a future of probable economic disruption, increased inequality and public debt as a result of COVID-19, Brexit and longstanding productivity stagnation, the answer is therefore 'probably nothing much'. Nothing, that is from outside. The overriding implication from our research is that residents of coalmining communities may have been overrun with development and regeneration agencies, but lack a sense of personal or community agency, in both the political and economic spheres. This is perhaps unsurprising, with very little control of local economic resources (including land) or employed capital exercised from within the former coalfields, fewer firms headquartered, and residents often dependent on outcommuting for employment, and out-migration for their children's careers (Jones, 2015). The restoration of a sense of autonomy would seem to be a prerequisite for attempts to reintegrate former mining communities into the economic mainstream. Or perhaps a better project is to restructure the economic mainstream so that it does not create so many peripheral, left behind communities in the first place.

\section{$\underline{\text { References }}$}

Abreu, M. \& Oner, O. (2020). Disentangling the Brexit vote: The role of economic, social and cultural contexts in explaining the UK's EU referendum vote. Environment and Planning A, 52 (7), 1434-1456.

Achten, S., \& Lessmann, C. (2019). Spatial inequality, geography and economic activity. CESifo Working Paper No. 7547. https://papers.ssrn.com/sol3/papers.cfm?abstract id $=3352910$

Agnisola, G., Weir, S., \& Johnson, K. (2019). The voices that matter: A narrative approach to understanding Scottish Fishers' perspectives of Brexit. Marine Policy, 110, 103563.

Barros, L., \& Santos Silva, M. (2019). \#EleNão: Economic crisis, the political gender gap, and the election of Bolsonaro (No. 242). IAI Discussion Papers. http://hdl.handle.net/10419/202044

Beatty, C., Fothergill, S., \& Wilson, I. (2008). England's seaside towns: A 'benchmarking' study. Her Majesty's Stationery Office.

Beatty, C., Fothergill, S., \& Gore, T. (2019). The state of the coalfields: Economic and social conditions in the former mining communities of England, Scotland and Wales. Centre for Regional Economic and Social Research, Sheffield Hallam University.

Beecham, R., Williams, N., \& Comber, A. (2020). Regionally-structured explanations behind arealevel populism: An update to recent ecological analyses. Plos one, 15(3), e0229974. 
Bell, S. E., \& Braun, Y. A. (2010). Coal, identity, and the gendering of environmental justice activism in central Appalachia. Gender \& Society, 24(6), 794-813.

Bell, S. E., \& York, R. (2010). Community economic identity: The coal industry and ideology construction in West Virginia. Rural Sociology, 75(1), 111-143.

Blackwell, M., Iacus, S. M., King, G., \& Porro, G. (2009). cem: Coarsened exact matching in Stata. The Stata Journal, 9(4), 524-546.

Bloodworth, J. (2016). Labour is Becoming a Historical Re-enactment Society, International Business Times. Available online at: https://www.ibtimes.co.uk/jeremy-corbyns-labour-tribute-act-socialismtrade-unions-back-nostalgic-leader-1570061, accessed August 5, 2020.

Boswell, J., Denham, J., Furlong, J., Killick, A., Ndugga, P., Rek, B., Ryan M., \& Shipp, J. (2020) Place-based politics and nested deprivation in the U.K.: Beyond Cities-towns, "Two Englands' and the 'Left Behind', Representation, DOI: 10.1080/00344893.2020.1751258.

Bright, N. G. (2011). 'Off The Model': resistant spaces, school disaffection and 'aspiration' in a former coal-mining community. Children's Geographies, 9(1), 63-78.

Cadwalladr, C., \& Graham-Harrison, E. (2018). Revealed: 50 million Facebook profiles harvested for Cambridge Analytica in major data breach. The Guardian, 17, 22.

Carrascal-Incera, A., McCann, P., Ortega-Argilés, R., \& Rodríguez-Pose, A. (2020). Uk interregional inequality in a historical and international comparative context. National Institute Economic Review, 253, R4-R17. DOI: https://doi.org/10.1017/nie.2020.26

Costa, C., Santana, P., Dimitroulopoulou, S., Burstrom, B., Borrell, C., Schweikart, J., ... \& Freitas, $\hat{A}$. (2019). Population health inequalities across and within European metropolitan areas through the lens of the EURO-HEALTHY Population Health Index. International Journal of Environmental Research and Public Health, 16(5), 836.

Coyle, D. (1999). The Weightless World: Strategies for Managing the Digital Economy. MIT press.

Del Vicario, M., Zollo, F., Caldarelli, G., Scala, A., \& Quattrociocchi, W. (2017). Mapping social dynamics on Facebook: The Brexit debate. Social Networks, 50, 6-16.

Diamond, J. (2004). Local regeneration initiatives and capacity building: Whose 'capacity' and 'building' for what?. Community Development Journal, 39(2), 177-189.

Dijkstra, L., Poelman, H., \& Rodríguez-Pose, A. (2020). The geography of EU discontent. Regional Studies, 54(6), 737-753

Emery, J. D. (2019). Geographies of belonging in the nottinghamshire coalfield: affect, temporality and deindustrialisation (Doctoral dissertation, University of Leicester).

Emery, J. (2020). Urban trauma in the ruins of industrial culture: Miners' Welfares of the Nottinghamshire coalfield, UK. Social \& Cultural Geography, 1-21.

Fabian, M., Breunig, R., \& De Neve, J. E. (2020). Bowling with Trump: Economic Anxiety, Racial Identification, and Well-Being in the 2016 Presidential Election (No. 13022). IZA Discussion Papers. 
Farrall, S., Gray, E., \& Mike Jones, P. (2020). The Role of Radical Economic Restructuring in Truancy from School and Engagement in Crime. The British Journal of Criminology, 60(1), 118-140.

Friedman, T. L. (2006). The world is flat: The globalized world in the twenty-first century (p. 593). London: Penguin.

Fukuyama, F. (2006). The end of history and the last man. Simon and Schuster.

Gardiner, B. (2020). Long-Run Growth Dynamics of British Cities and their Role in the Economy. University of Cambridge. https://doi.org/10.17863/CAM.51666

Hernández, E. (2018). Democratic discontent and support for mainstream and challenger parties: Democratic protest voting. European Union Politics, 19(3), 458-480.

Huggins, R., \& Thompson, P. (2019). The behavioural foundations of urban and regional development: Culture, psychology and agency. Journal of Economic Geography, 19(1), 121-146.

Iacus, S. M., King, G., \& Porro, G. (2008). Matching for causal inference without balance checking. Available at SSRN: http://dx.doi.org/10.2139/ssrn.1152391.

Jennings, W., Stoker, G., \& Twyman, J. (2016). The dimensions and impact of political discontent in Britain. Parliamentary Affairs, 69(4), 876-900.

Jones, C. (2015). On capital, space and the world system: a response to Ron Martin. Territory, Politics, Governance, 3(3), 273-293.

Jump, R. \& Michell, J. (2020). Deprivation and the electoral geography of Brexit https://www.researchgate.net/publication/339090435 Deprivation and the electoral geograp hy of Brexit, accessed 4th August, 2020.

McCann, P. (2016). The UK regional-national economic problem: Geography, globalisation and governance. Routledge.

McKenzie, L. (2017). The class politics of prejudice: Brexit and the land of no-hope and glory. The British Journal of Sociology, 68, S265-S280.

Mayer, A. (2019). National energy transition, local partisanship? Elite cues, community identity, and support for clean power in the United States. Energy Research \& Social Science, 50, 143-150.

Myrdal, G. (1957). Economic theory and under-development regions. Gerald Duckworth.

Norris, P., \& Inglehart, R. (2019). Cultural backlash: Trump, Brexit, and authoritarian populism. Cambridge University Press.

Nurse, A. \& Sykes, O. (2019). It's more complicated than that!: Unpacking 'Left Behind Britain' and some other spatial tropes following the UK's 2016 EU referendum. Local Economy: The Journal of the Local Economy Policy Unit. DOI: 10.1177/0269094219881356.

Olson-Hazboun, S. K. (2018). "Why are we being punished and they are being rewarded?" views on renewable energy in fossil fuels-based communities of the US west. The Extractive Industries and Society, 5(3), 366-374. 
Perchard, A. (2013). "Broken Men" and "Thatcher's Children": Memory and Legacy in Scotland's Coalfields. International Labor and Working-Class History, 84, 78-98.

Piketty, T. (2020). Capital and ideology. Harvard University Press

Pugh, R. E. (2014). 'Old wine in new bottles'? Smart Specialisation in Wales. Regional Studies, Regional Science, 1(1), 152-157.

Rennó, L. R. (2020) The Bolsonaro Voter: Issue Positions and Vote Choice in the 2018 Brazilian Presidential Elections. Latin American Politics and Society, 1-23. (July 2020, in press)

Reny, T. T., Collingwood, L., \& Valenzuela, A. A. (2019). Vote switching in the 2016 election: How racial and immigration attitudes, not economics, explain shifts in white voting. Public Opinion Quarterly, 83(1), 91-113.

Rodríguez-Pose, A. (2018). The revenge of the places that don't matter (and what to do about it). Cambridge journal of regions, economy and society, 11(1), 189-209.

Rodrik, D. (2018). What do trade agreements really do? Journal of Economic Perspectives, 32(2), 73-90.

Sandbu, M. (2020). The Economics of Belonging: A Radical Plan to Win Back the Left Behind and Achieve Prosperity for All. Princeton University Press.

Sanz-Hernández, A. (2020). How to change the sources of meaning of resistance identities in historically coal-reliant mining communities. Energy Policy, 139, 111353.

Steber, M. (2018). Fundamentals at stake: the Conservatives, industrial relations and the rhetorical framing of the miners' strike in 1984/1985. Contemporary British History, 32(1), 60-77.

Stoker, G. (2006). Explaining Political Disenchantment: finding pathways to democratic renewal. The Political Quarterly, 77(2), 184-194.

Tomaney, J. (2020). After coal: meanings of the Durham Miners' Gala. Frontiers in Sociology, 5, 32.

Ughetto, E., Cowling, M., \& Lee, N. (2019). Regional and spatial issues in the financing of small and medium-sized enterprises and new ventures. Regional Studies 53(5), 617-619.

Whiteley, P., Clarke, H. D., \& Stewart, M. C. (2020). Populism Plus: Voting for Donald Trump and Hillary Clinton in the 2016 US Presidential Election. In Authoritarian Populism and Liberal Democracy (pp. 87-105). Palgrave Macmillan, Cham. 
Appendix A: Data sources and variable descriptions

Variables are sourced from the UK Longitudinal Household Survey unless otherwise stated. In reporting the descriptive statistics, we use the most recent data available, typically Wave 9 of the survey (2017-19). In a few cases the relevant topics only appeared in earlier waves, and this is noted where applicable below.

\section{A1. Demographic variables}

Age: in years, also grouped into categories for the descriptive and matching analysis (16-24, 25-44, 45-64, and 65+).

Ethnicity: grouped into major categories including white (British, European, or other), black (Caribbean, African, or other), Asian (Indian, Pakistani, Bangladeshi, other South Asian, or SouthEast Asian), Mixed, and Other.

Born in the UK: whether the respondent was born in the United Kingdom.

Marital status: grouped into single (single or cohabitating), married (married or in a civil partnership), divorced (separated, divorced, or dissolved civil partnership), and widowed.

Household size: number of individuals of any age who are part of the household.

Number of children: all children who are part of the household, including step-children.

\section{A2. Economic variables}

Housing tenure: the tenure status of the respondent, grouped into owner-occupier, social-housing tenant, private tenant, and other (living with parents, in communal established, etc.).

School leaving age: the age in years when the respondent left full-time education.

Higher education qualification: whether the respondent has a higher-education degree. Other education categories are also available but are not used in the analysis.

Working: whether the respondent is working full- or part-time, or is self-employed, if the respondent is of working age (18-65).

Receives any state benefits: whether the respondent receives state benefits, if the respondent is of working age. Includes unemployment benefits, working tax credits, housing benefits, and health and disability benefits, but excludes universal benefits such as child benefit and the state pension.

Number of benefits received: the number of different state benefits received, intended to capture the breadth of reliance on welfare programmes.

Equivalised monthly bousebold income: the net monthly household income after tax and other deductions in the month before the survey, divided by the number of household members converted into adult equivalents using the OECD equivalence scale (1.0 for the first adult, 0.5 for each additional adult or child over 14, and 0.3 for each child under 14). This variable is deflated using the monthly Consumer Prices Index including owner occupiers' housing costs (CPIH), produced by the Office for National Statistics, with base April 2015. 
Poor household: whether the household falls below $60 \%$ of the median equivalised household income for the UK in a given year.

\section{A3. Wellbeing and social variables}

SF12-mental functioning: an index based on 12 questions that cover aspects of mental health, where 0 indicates the lowest level of health, and 100 indicates the highest level.

SF12-physical functioning: an index based on 12 questions that cover aspects of physical health, where 0 indicates the lowest level of health, and 100 indicates the highest level. Note that in the longitudinal analysis the sample is a balanced panel, with the same individuals observed over a period of nine years. As the sample ages, the value of this variable naturally increases over time.

Life satisfaction: satisfaction with life overall, on a 1-7 Likert scale, where 1 is "completely dissatisfied, and 7 is "completely satisfied".

Job satisfaction: satisfaction with present job, on a 1-7 Likert scale, where 1 is "completely dissatisfied, and 7 is "completely satisfied".

Prepared to take risks: extent to which the respondent is prepared to take risks, on a scale of 0-10. Only available in Wave 1.

Prepared to trust strangers: extent to which the respondent is prepared to risk trusting strangers, on a scale of $0-10$. Only available in Wave 1.

Neighbourbood belonging: whether the respondent agrees with the statement "I feel like I belong to this neighbourhood", on a 1-5 Likert scale, where 1 is "strongly disagree" and 5 is "strongly agree". Only available in Waves 1, 3, 6, and 9.

Cohesion index: an index adapted from Buckner's Neighbourhood Cohesion Instrument (Buckner, $1988^{17}$ ) to capture psychological sense of community, attraction to neighbourhood, and social interaction within a neighbourhood. Ranges from 4 "lowest cohesion" to 20 "highest cohesion". Only available in Waves 1, 3, 6, and 9 .

"Family suffers if mother works": extent to which the respondent agrees with the statement "Family suffers if mother works full-time", on a 1-5 Likert scale, where 1 is "strongly disagree" and 5 is "strongly agree. Available in Waves 2 and 4.

"Environmental crisis exaggerated": extent to which the respondent agrees with the statement "The socalled environmental crisis facing humanity has been greatly exaggerated", on a 1-5 Likert scale, where 1 is "strongly disagree" and 5 is "strongly agree". Available in Wave 4.

A4. Neighbourhood and district-level variables

Index of Multiple Deprivation (IMD): a relative measure of material deprivation for small census neighbourhoods (lower super-output areas, or LSOAs), incorporating income, employment, skills,

17 Buckner, J. C. (1988). The development of an instrument to measure neighborhood cohesion. American Journal of Community Psychology 16(6): 771-791. 
health, crime, housing, and living environment deprivation. The index is constructed separately for England, Scotland, and Wales, and is therefore not directly comparable. We use the adjusted index developed by Abel et al. (2016) ${ }^{18}$ that allows for cross-nation comparisons. Higher values indicate greater levels of deprivation.

Deprived area: whether the neighbourhood falls in the two highest quintiles of the IMD, that is, whether the neighbourhood is among the $20 \%$ most deprived in the UK.

Urban area: whether the neighbourhood is urban or rural.

Annual austerity cuts per person: the extent to which individuals in a local authority district (or equivalent unitary authority) were affected by budgetary cuts to state benefits that were introduced by the government in 2011 as part of the "austerity" programme, from Beatty \& Fothergill (2013) ${ }^{19}$.

\section{A5. Political efficacy and engagement variables}

Democracy works well: extent to which the respondent is satisfied with "the way democracy works in this country", ranging from 1 "very dissatisfied to 4 "very satisfied". Available in Waves 2, 3, 6 and 9 .

Interest in politics: extent to which the respondent is "interested in politics", on a scale ranging from 1 "not at all interested" to 4 "very interested". Available in all waves except for Wave 8.

Voting as a civic duty: extent to which the respondent agrees with the statement "I would be seriously neglecting my duty as a citizen if I didn't vote", on a 1-5 Likert scale, where 1 is "strongly disagree" and 5 is "strongly agree". Available in Waves 2, 3, 6 and 9.

Voting as a social norm: extent to which the respondent agrees with the statement "Most people around here usually vote in general elections", on a 1-5 Likert scale, where 1 is "strongly disagree" and 5 is "strongly agree". Available in Waves 2, 3, 6 and 9.

Personal benefits from voting: extent to which the respondent agrees with the statement "I feel a sense of satisfaction when I vote", on a 1-5 Likert scale, where 1 is "strongly disagree" and 5 is "strongly agree". Available in Waves 2, 3, 6 and 9.

Group benefits from voting: extent to which the respondent agrees with the statement "Voting is a good way to get benefits for groups that people care about, like pensioners and the disabled", on a 1-5 Likert scale, where 1 is "strongly disagree" and 5 is "strongly agree". Available in Waves 2, 3,6 and 9 .

Qualified to participate in politics: extent to which the respondent agrees with the statement "I consider myself to be well qualified to participate in politics", on a 1-5 Likert scale, where 1 is "strongly disagree" and 5 is "strongly agree". Available in Waves 3, 6 and 9.

\footnotetext{
18 Abel, G. A., Barclay, M. E., \& Payne, R. A. (2016). Adjusted indices of multiple deprivation to enable comparisons within and between constituent countries of the UK including an illustration using mortality rates. BMJ open, 6(11).

19 Beatty, C. \& Fothergill, S. (2013). Hitting the poorest places hardest: The local and regional impact of welfare reform. DOI: 10.7190/cresr.2017.6378897426.
} 
Well informed about politics: extent to which the respondent agrees with the statement "I think I am better informed about politics than most people", on a 1-5 Likert scale, where 1 is "strongly disagree" and 5 is "strongly agree". Available in Waves 3, 6 and 9.

Public officials don't care: extent to which the respondent agrees with the statement "Public officials don't care much about what people like me think", on a 1-5 Likert scale, where 1 is "strongly disagree" and 5 is "strongly agree". Available in Waves 3, 6 and 9.

Little say in what government does: extent to which the respondent agrees with the statement "People like me don't have any say in what the government does", on a 1-5 Likert scale, where 1 is "strongly disagree" and 5 is "strongly agree". Available in Waves 3, 6 and 9.

Supports no party: whether the respondent has indicated that they support no particular party, as opposed to supporting a specific party. Available in all waves except for Wave 8.

Votes for right-wing party: whether the respondent voted for the Conservatives, the UK Independence Party (UKIP), or the British Nationalist Party (BNP) at the previous general election. Available in all waves except for Wave 8.

Votes for nationalist party: whether the respondent voted for the UK Independence Party (UKIP), Plaid Cymru, or the Scottish Nationalist Party at the previous general election. Available in all waves except for Wave 8.

$U K$ should remain in EU: whether the respondent agrees or disagrees with the statement "Should the UK remain a member of the EU?". Available in Wave 8.

Intends to vote: whether the respondent intends to vote at the next general election. Available in Waves 2, 3, 6 and 9. 
Appendix B: Supplementary tables

Table B1. Descriptive statistics for variables included in the analysis.

\begin{tabular}{|c|c|c|c|c|c|c|}
\hline Variable & Obs & Mean & Std. Dev. & Min & $\operatorname{Max}$ & Period \\
\hline Age (years) & 33,655 & 49.31 & 18.76 & 16 & 103 & $2017-19$ \\
\hline Age 16-24 & 32,673 & 0.1 & 0.3 & 0 & 1 & 2017-19 \\
\hline Age 25-44 & 32,673 & 0.29 & 0.46 & 0 & 1 & 2017-19 \\
\hline Age 45-64 & 32,673 & 0.36 & 0.48 & 0 & 1 & 2017-19 \\
\hline Age 65+ & 32,673 & 0.25 & 0.43 & 0 & 1 & 2017-19 \\
\hline Annual austerity cuts per person & 33,657 & 476.51 & 116.43 & 177 & 914.01 & 2016 \\
\hline Born in England & 33,657 & 0.68 & 0.47 & 0 & 1 & $2017-19$ \\
\hline Born in Scotland & 33,657 & 0.08 & 0.28 & 0 & 1 & 2017-19 \\
\hline Born in the UK & 33,285 & 0.84 & 0.16 & 0 & 1 & 2017-19 \\
\hline Born in Wales & 33,657 & 0.06 & 0.23 & 0 & 1 & 2017-19 \\
\hline Coalmining area & 33,657 & 0.11 & 0.31 & 0 & 1 & 1981-2019 \\
\hline Cohesion index & 34,249 & 14.8 & 2.58 & 4 & 20 & 2014-16 \\
\hline Democracy works well & 30,595 & 2.39 & 0.81 & 1 & 4 & $2017-19$ \\
\hline Deprived area & 33,657 & 0.41 & 0.49 & 0 & 1 & $2017-19$ \\
\hline Environmental crisis exaggerated & 36,029 & 3.03 & 1.02 & 1 & 5 & $2012-14$ \\
\hline Equivalised monthly hh income & 32,809 & 1841.82 & 1503.02 & 0 & 69483.21 & $2017-19$ \\
\hline Family suffers if mother works & 36,143 & 2.86 & 1.11 & 1 & 5 & 2012-14 \\
\hline Group benefits from voting & 31,002 & 3.39 & 0.87 & 1 & 5 & $2017-19$ \\
\hline Higher education qualification & 32,967 & 0.4 & 0.49 & 0 & 1 & 2017-19 \\
\hline Household size & 32,809 & 2.93 & 1.55 & 1 & 13 & 2017-19 \\
\hline IMD quintile & 33,657 & 2.99 & 1.42 & 1 & 5 & $2017-19$ \\
\hline IMD score & 33,657 & 22.11 & 15.57 & 0.5 & 85.6 & 2017-19 \\
\hline Intends to vote & 27,622 & 8.04 & 3.18 & 0 & 10 & 2017-19 \\
\hline Interest in politics & 31,214 & 2.44 & 0.92 & 1 & 4 & $2017-19$ \\
\hline Job satisfaction & 18,664 & 5.36 & 1.36 & 1 & 7 & 2017-19 \\
\hline Life satisfaction & 31,266 & 5.14 & 1.49 & 1 & 7 & 2017-19 \\
\hline Little say in what govt. does & 30,949 & 3.2 & 1.03 & 1 & 5 & $2017-19$ \\
\hline Married or in civil partnership & 32,514 & 0.54 & 0.5 & 0 & 1 & 2017-19 \\
\hline Neighbourhood belonging & 31,245 & 3.71 & 0.92 & 1 & 5 & 2017-19 \\
\hline Number of benefits received & 33,657 & 1.48 & 1.64 & 0 & 11 & 2017-19 \\
\hline Number of children & 32,809 & 0.54 & 0.95 & 0 & 8 & 2017-19 \\
\hline Owner-occupier & 32,610 & 0.73 & 0.44 & 0 & 1 & 2017-19 \\
\hline Personal benefits from voting & 30,048 & 3.58 & 0.93 & 1 & 5 & 2017-19 \\
\hline Poor household & 33,657 & 0.15 & 0.36 & 0 & 1 & 2017-19 \\
\hline Prepared to take risks & 37,738 & 5.23 & 2.67 & 0 & 10 & $2009-11$ \\
\hline Prepared to trust strangers & 37,750 & 3.5 & 2.53 & 0 & 10 & 2009-11 \\
\hline Private tenant & 32,610 & 0.1 & 0.3 & 0 & 1 & 2017-19 \\
\hline Public officials don't care & 30,944 & 3.28 & 0.97 & 1 & 5 & 2017-19 \\
\hline Qualified to participate in politics & 30,956 & 2.96 & 1.1 & 1 & 5 & 2017-19 \\
\hline Receives any state benefits & 33,657 & 0.61 & 0.49 & 0 & 1 & $2017-19$ \\
\hline School leaving age & 30,256 & 16.39 & 1.3 & 10 & 26 & $2017-19$ \\
\hline SF12-mental functioning & 30,890 & 48.44 & 10.63 & 0 & 76 & 2017-19 \\
\hline SF12-physical functioning & 30,890 & 49.48 & 11.13 & 5 & 74 & $2017-19$ \\
\hline Social housing & 32,610 & 0.16 & 0.36 & 0 & 1 & 2017-19 \\
\hline Supports no party & 11,409 & 0.43 & 0.49 & 0 & 1 & 2017-19 \\
\hline UK should remain in EU & 32,143 & 0.58 & 0.49 & 0 & 1 & 2016-18 \\
\hline Urban area & 33,657 & 0.78 & 0.41 & 0 & 1 & $2017-19$ \\
\hline Votes for nationalist party & 11,507 & 0.07 & 0.26 & 0 & 1 & $2017-19$ \\
\hline Votes for right-wing party & 6,368 & 0.38 & 0.48 & 0 & 1 & 2017-19 \\
\hline Voting as a civic duty & 30,413 & 3.91 & 1.09 & 1 & 5 & 2017-19 \\
\hline Voting as a social norm & 30,613 & 3.62 & 0.72 & 1 & 5 & $2017-19$ \\
\hline Well informed about politics & 30,942 & 2.85 & 1.01 & 1 & 5 & $2017-19$ \\
\hline White ethnicity & 33,507 & 0.8 & 0.4 & 0 & 1 & 2017-19 \\
\hline Working & 33,620 & 0.54 & 0.5 & 0 & 1 & $2017-19$ \\
\hline
\end{tabular}


Note: The table shows descriptive statistics including the number of observations, mean, standard deviation, minimum and maximum values, and the latest period for which the data are available. These statistics are reported for reference purposes and are not weighted.

Table B2. Number and percentage of control/treated observations matched.

\begin{tabular}{lllll}
\hline Survey wave & $\begin{array}{l}\text { No. control } \\
\text { observations } \\
\text { matched }\end{array}$ & $\begin{array}{l}\text { No. treated } \\
\text { observations } \\
\text { matched }\end{array}$ & $\begin{array}{l}\text { \% control } \\
\text { observations } \\
\text { matched }\end{array}$ & $\begin{array}{l}\% \text { treated } \\
\text { observations } \\
\text { matched }\end{array}$ \\
\hline Wave 1 (2009-11) & 40653 & 4634 & 92.2 & 96.1 \\
Wave 4 (2012-14) & 36076 & 4999 & 93.2 & 96.4 \\
Wave 8 (2016-18) & 29169 & 3683 & 88.8 & 94.2 \\
Wave 9 (2017-19) & 26602 & 3388 & 88.7 & 94.1 \\
\hline
\end{tabular}

Table B3. Imbalance between treated and control samples, before and after matching (in Wave 9).

Before CEM matching

Multivariate L1 distance: 0.313

Univariate imbalance:

\begin{tabular}{lccccccc}
\hline Matching variable & L1 & mean & min & $25 \%$ & $50 \%$ & $75 \%$ & $\max$ \\
\hline Age group & 0.0404 & 0.0893 & 0 & 0 & 0 & 1 & 0 \\
Higher education & 0.0939 & - & 0 & 0 & 0 & 0 & 0 \\
Housing tenure & 0.0366 & - & 0 & 0 & 0 & -1 & 0 \\
Poor household & 0.0193 & 0.0193 & 0 & 0 & 0 & 0 & 0 \\
IMD quintile & 0.1160 & 0.3143 & 0 & 0 & 0 & 0 & 0 \\
Urban & 0.1080 & - & 0 & -1 & 0 & 0 & 0 \\
UK nation & 0.2245 & 0.4330 & 0 & 0 & 0 & 2 & 0 \\
\hline
\end{tabular}

\section{After CEM matching}

Multivariate L1 distance: 0.000

Univariate imbalance:

\begin{tabular}{lccccccc}
\hline & L1 & mean & $\min$ & $25 \%$ & $50 \%$ & $75 \%$ & $\max$ \\
\hline Age group & 0 & 0 & 0 & 0 & 0 & 0 &. \\
Higher education & 0 & 0 & 0 & 0 & 0 & 0 &. \\
Housing tenure & 0 & 0 & 0 & 0 & 0 & 0 &. \\
Poor household & 0 & 0 & 0 & 0 & 0 & 0 & 0 \\
IMD quintile & 0 & 0 & 0 & 0 & 0 & 0 & 0 \\
Urban & 0 & 0 & 0 & 0 & 0 & 0 & 0 \\
UK nation & 0 & 0 & 0 & 0 & 0 & 0 & 0 \\
\hline
\end{tabular}

Note: Column 4 shows difference in means, asterisks denote statistical significance, ${ }^{* * *}$ significant at $1 \%$ level, ${ }^{* *}$ significant at 5\% level, ${ }^{*}$ significant at $10 \%$ level. 
(a) Employment in the "gas, energy, and water" industry in 1981, and geological coal deposits

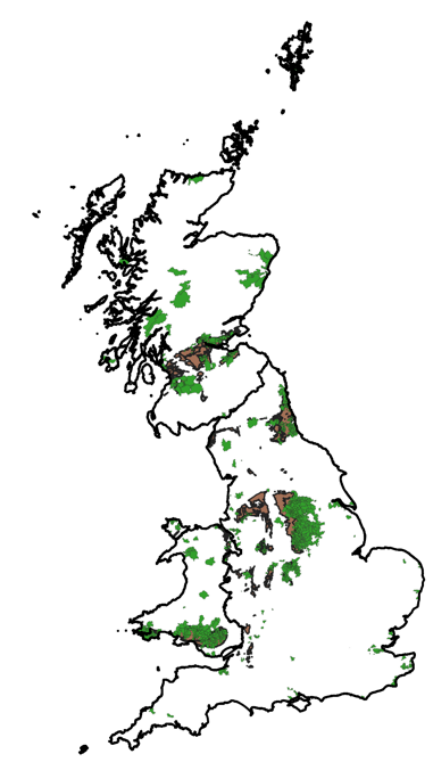

High employment in coal, energy, and water Geological coal deposits (b) LSOAs within high-employment wards, and within 10 miles of geological coal deposits

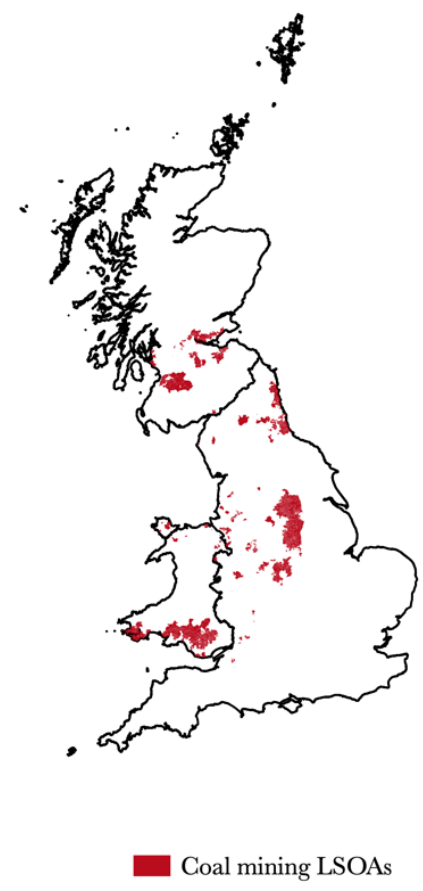

Figure C1. Location of the coalmining areas used in the analysis. The maps show (a) wards with at least $10 \%$ of the adult male population employed in "coal, energy, and water" in 1981 as captured in the 1981 Census, and the location of geological coal deposits, and (b) LSOAs designated as coalmining areas in the analysis. 
Equivalised monthly household income (2015 GBP), full sample

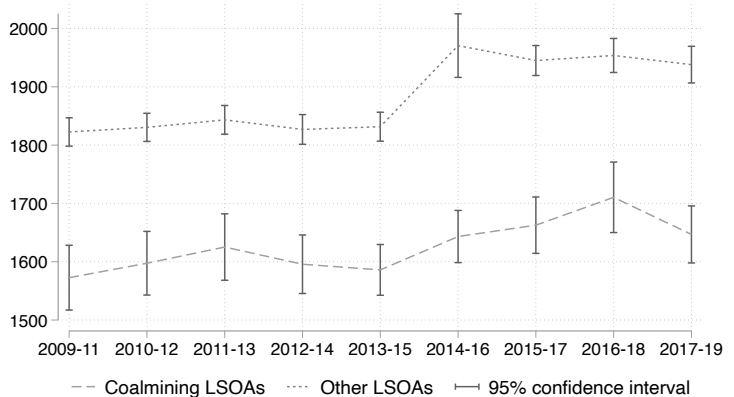

Equivalised monthly household income (2015 GBP), matched sample

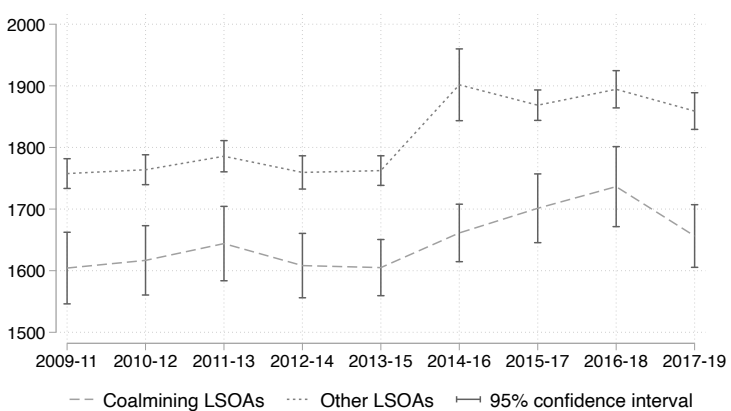

Figure C2. Equivalised monthly household income (in 2015 GBP) of households in coal-mining and other areas, over the period 2009-2019, for full and matched samples. The dashed and dotted lines show sample average treatment effect (SATT) estimates for coalmining and other areas, respectively, and vertical lines show 95\% confidence intervals. SATT estimates are obtained using a weighted regression of the outcome variable on a coalmining area dummy variable, with weights given by a combination of sampling and design weights, non-response rates, and Coarsened Exact Matching (CEM) weights. Each estimate corresponds to one wave of the UKLHS survey.

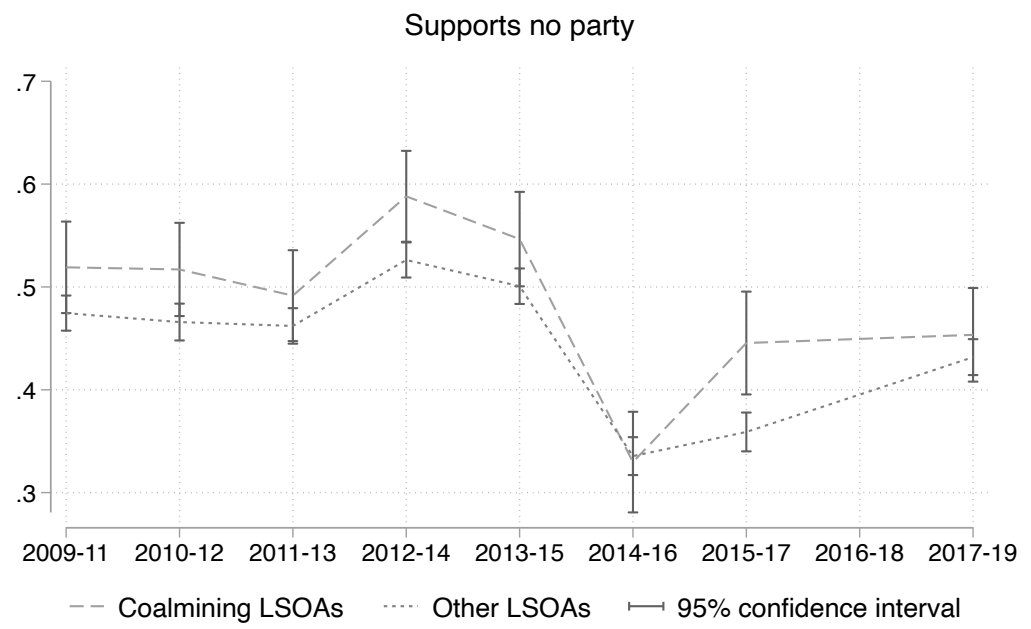

Figure C3. Share of individuals who support no particular political party in coal-mining and other areas, over the period 2009-2019, showing average treatment effect (SATT) estimates and 95\% confidence intervals for individuals in the matched sample. The SAT'T estimates are obtained using a weighted regression of the standardised outcome variable on a coalmining area dummy variable, with weights given by a combination of sampling and design weights, non-response rates, and Coarsened Exact Matching (CEM) weights. 
Life satisfaction

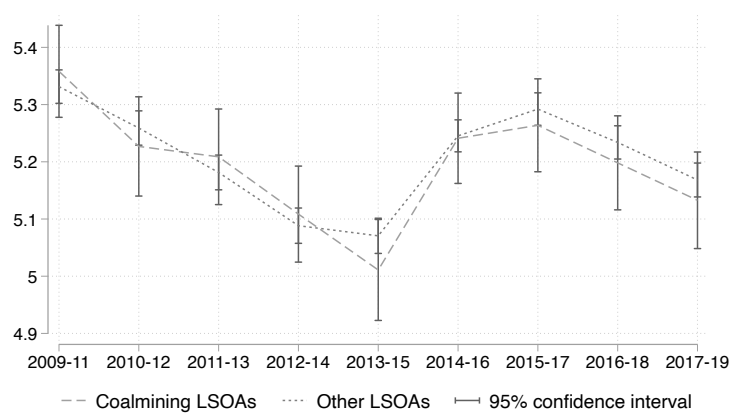

SF12-physical functioning

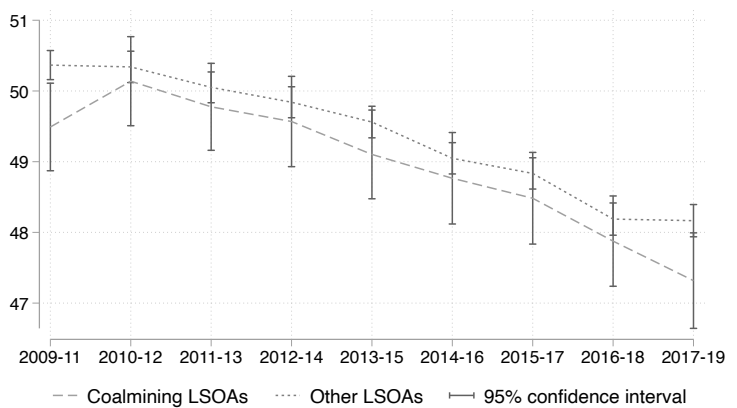

Job satisfaction

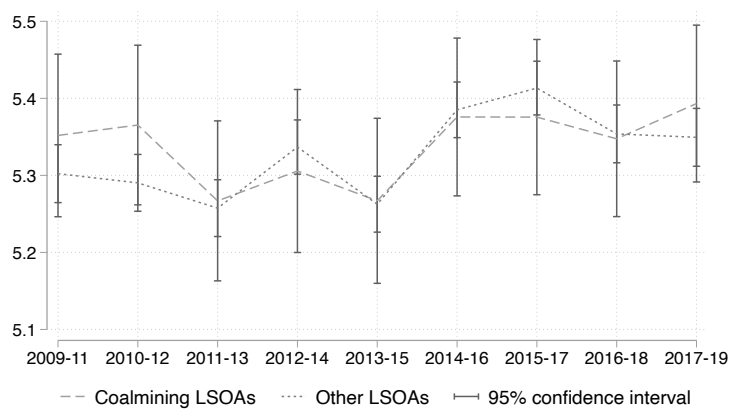

SF12-mental functioning

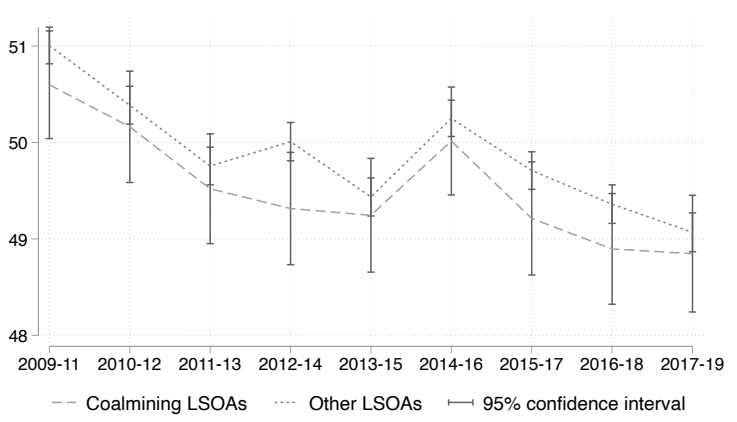

Figure C4. Health and wellbeing outcomes in coal-mining and other areas, over the period 2009-2019, showing average treatment effect (SATT) estimates and 95\% confidence intervals for individuals in the matched sample. The SATT estimates are obtained using a weighted regression of the standardised outcome variable on a coalmining area dummy variable, with weights given by a combination of sampling and design weights, non-response rates, and Coarsened Exact Matching (CEM) weights. 